\title{
Desain Kapal Pembangkit Listrik Tenaga Gas untuk Wilayah Indonesia
}

\author{
Kamaluddin, Ir. Wasis Dwi Aryawan, M.Sc., Ph.D. \\ Jurusan Teknik Perkapalan, Fakultas Teknologi Kelautan, Institut Teknologi Sepuluh Nopember (ITS) \\ Jl. Arief Rahman Hakim, Surabaya 60111 Indonesia \\ e-mail: wasis@na.its.ac.id
}

\begin{abstract}
Abstrak - Hingga saat ini, di Indonesia masih ada 12.659 desa tertinggal yang belum memperoleh akses listrik dari jaringan Perusahaan Listrik Negara (PLN), bahkan 2.519 desa diantaranya belum teraliri listrik sama sekali.Pada tanggal 8 Desember 2015 Presiden Joko Widodo meresmikan operasional pembangkit listrik di atas kapal yang menyewa dari Turki untuk daerah Amurang, Minahasa Selatan, Sulawesi Utara. Selanjutnya juga akan didatangkanpower plant serupa dari Turki untuk beberapa lokasi antara lain Sumatera Bagian Utara, Kupang, Ambon, dan Lombok. PLN mengklaim ada efisiensi sebesar Rp. 350 miliar per tahun dibanding menggunakan pembangkit listrik tenaga diesel (PLTD). Tujuan dari Tugas Akhir ini adalah untuk mendapatkan desain konseptual kapal pembangkit listrik tenaga gas yang memiliki kemampuan mobilitas sebagai upaya untuk memenuhi kebutuhan sumber listrik di wilayah Indonesia. Sehingga pemerintah dapat cepat tanggap terhadap daerah yang mengalami krisis listrik di Indonesia.Proses desain kapal dimulai dari studi literatur dan penentuanoutput daya listrik kapal menggunakan informasi kondisi kelistrikan Nasional dari Kementerian Energi dan Sumber Daya Mineral Indonesia.Didapatkan daya listrik kapal yang didesain yaitu 144 MW. Kemudian mencari ukuran utama kapal. Setelah itu dilakukan perhitungan teknis berupa perhitungan berat, trim, freeboard, dan stabilitas. Ukuran utama yang didapatkan adalah Lpp $=150 \mathrm{~m} ; B=31 \mathrm{~m} ; \mathrm{H}=16 \mathrm{~m} ; \mathrm{T}=4,9 \mathrm{~m}$. Dari data tersebut kemudian dibuatLines Plan dan General Arrangement.
\end{abstract}

Kata Kunci - defisit listrik, Indonesia, kapal pembangkit listrik

\section{PENDAHULUAN}

I NDONESIA yang merupakan negara kepulauan cenderung memiliki permasalahan terkait dengan pemerataan pembangunan, khususnya pembangunan di daerah kepulauan. Hingga saat ini, masih ada 12.659 desa tertinggal yang belum memperoleh akses listrik dari jaringan Perusahaan Listrik Negara (PLN), bahkan 2.519 desa diantaranya belum teraliri listrik sama sekali. Desa-desa ini sebagian besar tersebar di Provinsi Papua dan di kawasan Indonesia Timur lainnya.

Pemerintah, dalam rangka mewujudkan "terang untuk semua", meluncurkan Program Indonesia Terang atau PIT. Program ini bertujuan menyediakan akses listrik bagi seluruh rakyat Indonesia. Satu diantara langkahnya, pada tanggal 8 Desember 2015 Presiden Joko Widodo meresmikan operasional pembangkit listrik di atas kapal atau Marine Vessel Power Plant (MVPP) milik PT Perusahaan Listrik Negara. Presiden menganggap fasilitas yang bisa berpindah tempat tersebut sebagai pilihan tepat untuk mengatasi kekurangan listrik di sejumlah daerah.

PT PLN (Persero) menyewa Pembangkit Listrik Tenaga Gas/PLTG terapung, Kapal Marine Vessel Power Plant (MVPP) Karadeniz Powership Zeynep Sultan, berkapasitas 120 Mega Watt (MW). Kapal berisi pembangkit listrik yang baru datang dari Turki ini akan menuju Amurang, Minahasa Selatan, Sulawesi Utara. Kemudian PLN juga akan mendatangkan power plant serupa untuk beberapa lokasi antara lain Sumatera Bagian Utara (240 MW), Kupang (60 MW), Ambon (60 MW), dan Lombok (60 MW) (Wicaksono, 2015). PLN akan membeli listrik dari kapal ini dengan harga Rp $1.700 \mathrm{Rp} 1.800$ per kilowatt jam $(\mathrm{kWh})$. Dengan begitu PLN mengklaim ada efisiensi sebesar $\mathrm{Rp} 350$ miliar per tahun dibanding menggunakan pembangkit listrik tenaga diesel (PLTD).

Kapal pembangkit listrik ini digunakan di daerah yang mengalami krisis sumber listrik, sembari menunggu perbaikan atau pembangunan pembangkit listrik yang membutuhkan waktu relatif lama, yaitu 3 sampai dengan 5 tahun. Karena kemampuan mobilitasnya, menjadikan kapal pembangkit listrik ini menjadi solusi cepat dalam penyediaan sumber listrik di daerah-daerah yang mengalami krisis sumber listrik dan sangat cocok diaplikasikan di negara kepulauan seperti Indonesia. Sehingga pemerintah dapat cepat tanggap terhadap daerah yang mengalami krisis listrik.

Untuk memenuhi kebutuhan kapal pembangkit listrik di wilayah Indonesia, maka dalam Tugas Akhir ini dibahas desain kapal pembangkit listrik tenaga gas yang memiliki kemampuan mobilitas sebagai upaya untuk memenuhi kebutuhan sumber listrik di wilayah Indonesia.

\section{METODOLOGI}

Tahap awal yang dilakukan dalam pengerjaan Tugas Akhir adalah dimulai dengan studi literatur dan pengumpulan data untuk memahami permasalahan yang ada, selanjutnya dapat disusun menjadi sebuah hipotesa.

Data yang didapatkan meliputi data kondisi kelistrikan di Indonesia, kondisi perairan di Indonesia, dan sistem pembangkit listrik tenaga gas. Data ini digunakan untuk menunjang pengerjaan Tugas Akhir. Sedangkan studi literatur dilakukan untuk mengetahui hal-hal yang berkaitan dengan kapal pembangkit listrik tenaga gas dan referensi-referensi perhitungan pada Tugas Akhir sebelumnya. Pada tahap ini 
dilakukan studi pustaka terhadap berbagai referensi terkait dengan topik Tugas Akhir. Selain untuk mengetahui, tahapan ini juga untuk mencari konsep dan metode yang sesuai agar dapat menyelesaikan masalah yang ada. Studi literatur ini juga meliputi pencarian referensi atas teori-teori terkait atau hasil penelitian sebelumnya.

Kemudian dilakukan studi ke PT.PJB UP Gresik untuk mengetahui sistem pembangkit listrik tenaga gas yang optimal dan cocok diaplikasikan pada kapal pembangkit listrik tenaga gas yang akan didesain. Hasil tahapan ini kemudian diaplikasikan pada pembuatan layout pembangkit listrik tenaga gas di dalam kapal, sehingga perencanaan sistem pembangkit listrik tenaga gas yang dihasilkan lebih optimum.

Untuk tahap pengerjaan dimulai dengan penentuan data payload kapal beruba luasan deck untuk Power Plant yang dibutuhkan dan penentuan ukuran utama kapal. Payload kapal ditentukan dengan mencari defisit listrik terbesar di Indonesia. Setelah itu dilanjutkan dengan pencarian katalog-katalog pembangkit listrik tenaga gas sesuai dengan kebutuhan listrik yang telah didapatkan. Kemudian dari berbagai data dan studi literatur dibuat layout dari pembangkit listrik tenaga gas sesuai dengan kebutuhan. Sedangkan ukuran utama kapal didapatkan dengan menggunakan metode Parametric Design Approach, yaitu dengan menggunakan $5 \mathrm{kapal}$ pembanding sejenis yang kemudian dilakukan regresi pada ukuran-ukuran utama kapal tersebut.

Setelah owner requirements didapat, maka dilakukan ploting layout awal sistem pembangkit listrik tenaga gas ke dalam layout awal kapal yang didesain.

Kemudian dilakukan perhitungan teknis dan pengecekan batasan teknis, meliputi pengecekan bouyancy kapal, trim kapal, freeboard kapal, dan stabilitas kapal. Perhitungan stabilitas kapal menggunakan bantuan dari software Maxsurf Advanced Stability Education Version.

Pada pengerjaan Tugas Akhir ini dilakukan pengubahan ukuran utama awal kapal, karena pada perhitungan dengan menggunakan ukuran utama awal kapal diketahui bahwa berat kapal tidak sesuai dengan margin berat yang diijinkan, yaitu 5\%. Pengubahan ukuran utama ini mengacu pada ukuran utama MVPP (Motor Vessel Power Plant) Karadeniz Karpowership Zeynep Sultan yang sekarang sedang beroperasi di Amurang, Sulawesi Utara. Setelah semua batasan teknis terpenuhi, kemudian didesain Lines Plan dan General Arrangement menggunakan bantuan software Maxsurf Education Version dan $C A D$.

Desain General Arrangement menggunakan referensi dari interior kapal pembangkit listrik yang telah beroperasi dan layout pembangkit listrik tenaga gas yang telah tersedia pada katalog turbin gas yang digunakan.

Penyusunan kesimpulan dari keseluruhan proses desain kapal pembangkit listrik tenaga gas. Kesimpulan tersebut merupakan jawaban dari keseluruhan permasalahan yang ada meliputi evaluasi ketercapaian tujuan penelitian. Dilakukan juga penyusunan saran yang dapat digunakan untuk penelitian selanjutnya. Pada tahapan ini juga dilakukan penyusunan laporan Tugas Akhir yang merupakan keseluruhan report proses desain kapal PLTG yang telah dilakukan.

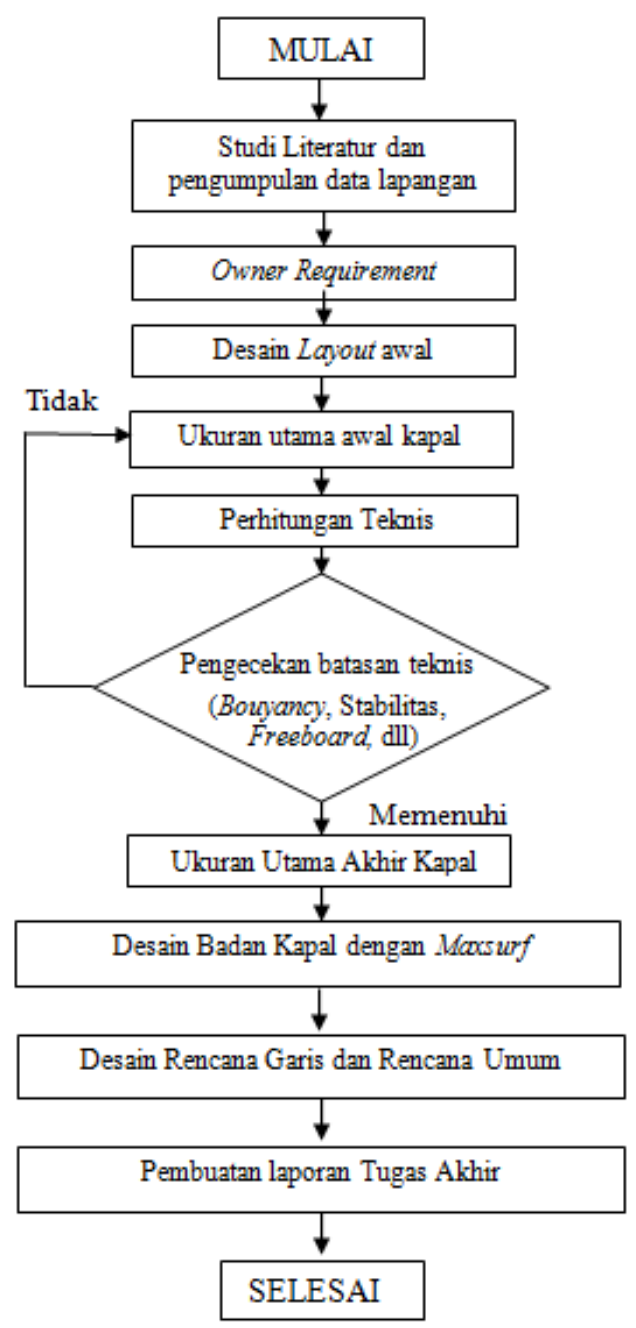

Gambar. 1. Diagram alir metodologi pengerjaan Tugas Akhir.

\section{ANALISA DAN PEMBAHASAN}

Kapal pembangkit listrik tenaga gas ini merupakan kapal general kargo yang memiliki pembangkit listrik tenaga gas di dalamnya. Kapal ini memiliki kemampuan mobilitas ke seluruh daerah di Indonesia untuk menanggapi krisis listrik yang terjadi di daerah-daerah di Indonesia secara cepat. Oleh karena itu tidak digunakan barge, karena dibutuhkan kapal yang memiliki hambatan yang minimal.

Ditentukan homebase dari kapal ini di Pelabuhan Tanjung Perak Surabaya, karena strategis untuk menjangkau Indonesia bagian barat maupun Indonesia bagian timur. Oleh karena itu untuk menentukan kebutuhan bakar main engine kapal, digunakan jarak daerah terjauh dari Surabaya, yaitu di daerah Jayapura dengan jarak pelayaran $2451 \mathrm{~nm}$. Kecepatan kapal menggunakan referensi kecepatan dari MVPP Karadeniz Powership Zeynep Sultan, yaitu 9 knot. Sehingga didapatkan lama pelayaran kapal adalah 11,3 hari.

Dalam operasionalnya kapal ini menggunakan storage bahan bakar pembangkit listrik tenaga gas di luar kapal. Baik storage dari pembangkit listrik yang sudah ada, maupun menggunakan bantuan dari tanker untuk menyuplai operasional dari kapal PLTG ini. Bahan bakar dari luar kapal akan dipompa ke dalam 
tangki bahan bakar pembangkit tenaga gas di dalam kapal yang didesain dapat menampung bahan bakar untuk operasional daya maksimal selama 56 jam. Hal tersebut bertujuan agar pompa tidak bekerja secara terus menerus, selain itu waktu tersebut juga bertujuan untuk memberikan waktu pemasangan instalasi pergantian tanker yang mensuplai bahan bakar ataupun untuk isi ulang storage bahan bakar diluar kapal bila habis. Sehingga kapal pembangkit listrik tenaga gas ini tetap dapat beroperasi walaupun sedang dilakukan pergantian tanker pensuplai bahan bakar ataupun refill bahan bakar pada storage diluar kapal.

Penentuan payload kapal yang didesain menggunakan referensi dari Kementerian Energi dan Sumber Daya Mineral Indonesia pada Gambar 1 dan katalog-katalog mesin yang didapatkan. Didapatkan defisit listrik terbesar di Indonesia adalah di daerah Sumatera Selatan-Bengkulu-Lampung, yaitu 140,9499 MW. Didapatkan katalog pembangkit listrik tenaga gas dengan output daya listrik 144 MW. Setelah itu dari data dan studi literatur dibuat desain layout dari pembangkit listrik, yang nantinya luasan deck yang didapatkan menjadi payload dari kapal PLTG yang didesain.

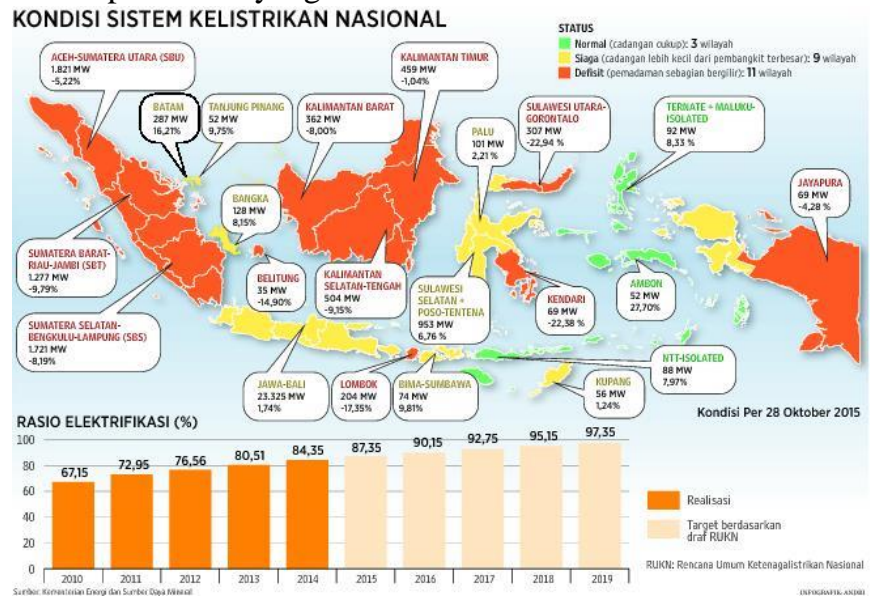

Gambar. 2. Kondisi sistem kelistrikan Nasional tanggal 28 Oktober 2015.

Dari penentuan layout awal kapal, payload, dan kecepatan, didapat owner requirement pada Tabel 1.

Tabel 1.

Tabel Owner Requirement kapal PLTG yang didesain

\begin{tabular}{lll}
\hline \hline No & \multicolumn{1}{c}{ Data desain } & \multicolumn{1}{c}{ Keterangan } \\
\hline 1 & Jenis kapal & Kapal pembangkit listrik tenaga gas \\
2 & Jenis muatan & Pembangkit listrik tenaga gas \\
3 & Jumlah crew & 24 orang \\
4 & Output daya listrik & $144 \mathrm{MW}$ \\
5 & Kecepatan kapal & 9 knot \\
7 & Radius pelayaran & $2451 \mathrm{~nm}$ \\
8 & Daerah Pelayaran & Pelayaran Indonesia \\
\hline \hline
\end{tabular}

Ukuran utama awal kapal didapatkan melalui regresi dari kapal-kapal pembangkit listrik tenaga gas yang telah beroperasi. Kapal pembanding yang digunakan ditampilkan pada Tabel 2.
Tabel 2.

Kapal pembanding yang digunakan

\begin{tabular}{lccccc}
\hline \hline \multicolumn{1}{c}{ Nama } & $\begin{array}{c}\text { Daya } \\
(\mathrm{MW})\end{array}$ & $\mathrm{L}(\mathrm{m})$ & $\mathrm{B}(\mathrm{m})$ & $\mathrm{H}(\mathrm{m})$ & $\mathrm{T}(\mathrm{m})$ \\
\hline Zeynep Sultan & 120 & 150,6 & 31,0 & 15,5 & 4,90 \\
Rauf Bey & 200 & 233,8 & 32,2 & 18,7 & 13,6 \\
Kaya Bey & 220 & 233,8 & 32,2 & 18,7 & 13,6 \\
Irem Sultan & 110 & 140,1 & 29,0 & 5,31 & 4,43 \\
Dogan Bey & 144 & 165,0 & 31,0 & 15,0 & 10,7 \\
\hline \hline
\end{tabular}

Ukuran utama awal kapal dari hasil regresi adalah Lpp = $168,21 \mathrm{~m}, \mathrm{~B}=30,683 \mathrm{~m}, \mathrm{H}=13,081 \mathrm{~m}, \mathrm{~T}=7,9012 \mathrm{~m}$. Pada perhitungan selanjutnya diketahui bahwa ukuran utama awal ini tidak memenuhi batasan teknis berat kapal, karena memiliki margin berat yang besar yaitu $48,851 \%$. Sedangkan margin maksimal berat kapal yang dijinkan adalah 5\%. Oleh karena itu dilakukan penggantian ukuran utama yang mengacu pada kapal MVPP Karadeniz Poweship Zeynep Sultan.

Didapatkan ukuran utama baru kapal PLTG Lpp $=155,5 \mathrm{~m}$; B $=31 \mathrm{~m} ; \mathrm{H}=16 \mathrm{~m} ; \mathrm{T}=7 \mathrm{~m}$. Dilakukan pengecekan ukuran utama terhadap batasan-batasan perbandingan ukuran utama yang didapatkan dari referensi buku Principle of Naval Architecture Vol.I [1].

Perhitungan koefisien menggunakan referensi dari Parametric Ship Design [2]. Adapun hasil perhitungannya adalah sebagai berikut,

$\begin{array}{ll}\mathrm{C}_{\mathrm{B}} & =0,706 \\ \mathrm{C}_{\mathrm{M}} & =0,986 \\ \mathrm{C}_{\mathrm{P}} & =0,716 \\ \mathrm{C}_{\mathrm{WP}} & =0,802 \\ \mathrm{LCB} & =5,545 \text { dari midship } \\ \nabla & =24778,450 \mathrm{~m}^{3} \\ \Delta & =25397,911 \text { ton }\end{array}$

Perhitungan hambatan kapal menggunakan metode Holtrop dan Mennen dari referensi buku Principle of Naval Architecture Vol.II Resistance, Propulsion and Vibration [3].

Penentuan daya motor induk ini dimulai dari perhitungan EHP, THP, DHP, SHP, dan BHP. Hasil perhitungan tersebut selanjutnya ditambahkan margin akibat letak kamar mesin dan daerah pelayaran, adapun hasil perhitungannya adalah sebagai berikut:

$\begin{array}{ll}\text { EHP } & =767,233 \mathrm{~kW} \\ \text { THP } & =743,197 \mathrm{~kW} \\ \text { DHP } & =1631,768 \mathrm{~kW} \\ \text { SHP } & =1656,617 \mathrm{~kW} \\ \text { BHP } & =1707.763 \mathrm{~kW}\end{array}$

Koreksi letak kamar mesin:

Koreksi $=3 \%$ untuk kamar mesin dibelakang

Koreksi daerah pelayaran:

Koreksi $=10-15 \%$ untuk perairan Indonesia

Koreksi $=3 \%+15 \% \times 1707.763$

Total kebutuhan power mesin adalah:

Daya mesin $=1929,772 \mathrm{~kW}=2587,863 \mathrm{HP}$

Komponen LWT kapal yang didesain terdiri dari berat Power Plant, berat permesinan kapal, berat equipment dan outfitting serta berat baja kapal. Perhitungan berat baja menggunakan 
metode Harvald \& Jensen [4]. Adapun hasil dari perhitungan LWT dapat dilihat pada Tabel 3.

Tabel 3.

Rangkuman berat LWT kapal PLTG yang didesain

\begin{tabular}{lrc}
\hline \multicolumn{1}{c}{ Item } & Value & Unit \\
\hline Berat Power Plant & & \\
\hline Gas Turbine + base & 680,00 & ton \\
Lube oil tank, starting means and auxiliaries & 240,00 & ton \\
Generator & 930,00 & ton \\
Reduction Gear & 100,00 & ton \\
Air intake system & 272,00 & ton \\
Exhaust system & 88,00 & ton \\
Gas valve compartment & 20,00 & ton \\
Steam Turbine & 250,00 & ton \\
Heat Recovery Steam Generator (HRSG) & 600,00 & ton \\
Berat total Power Plant & $\mathbf{3 1 8 0 , 0 0}$ & ton \\
\hline \hline Berat Permesinan Kapal & & \\
\hline Main Engine & 17,00 & ton \\
Gear Box & 1,72 & ton \\
Poros Propeller & 4,09 & ton \\
Propeller & 9,80 & ton \\
Lain-lain & 135,08 & ton \\
Berat total Permesinan Kapal & $\mathbf{8 7 8 5 , 4 5}$ & ton \\
\hline \hline Berat Baja Kapal & $\mathbf{1 6 7 , 6 9}$ & ton \\
\hline Total Berat Baja Kapal & & \\
\hline \hline Berat Peralatan dan Perlengkapan & & \\
\hline Peralatan dan Perlengkapan & $\mathbf{2 5 3 8 , 6 9}$ & ton \\
Grup IV & & \\
Berat total Peralatan dan Perlengkapan & $\mathbf{7 3 2 , 0 0}$ & ton \\
\hline \hline Berat Ballast & & ton \\
\hline \hline Berat Ballast & & \\
Total LWT & & \\
\hline \hline & & \\
\hline
\end{tabular}

Komponen DWT kapal diantaranya adalah berat bahan bakar, minyak pelumas, air tawar, HFO, provision, crew, dan luggage. Hasil perhitungannya adalah sebagai berikut:

$$
\begin{aligned}
\text { DWT } & =\text { Wconsumable } \\
& =2042,661 \text { ton }
\end{aligned}
$$

Displacement kapal dihitung berdasarkan ukuran utama dan koefisien-koefisien ukuran utama kapal dibandingkan dengan Displacement kapal dihitung berdasarkan pada LWT dan DWT kapal PLTG. Maksudnya dihitung selisihnya untuk dilakukan koreksi, apakah memenuhi dengan koreksi displacement sebesar 5\%. Koreksi yang didapatkan dari perhitungan yang telah dilakukan adalah sebesar 3,746\%, sehingga margin berat diterima.

Untuk menghitung trim, digunakan persamaan dari Parson (2001) [5] yaitu:

$$
\begin{aligned}
\text { Trim } & =T_{a}-T_{f} \\
& =\frac{\Delta(L C G-L C B) \cdot L_{p p}}{G M_{L}}
\end{aligned}
$$

LCG diperhitungkan sebagai suatu kesatuan titik berat komponen-komponen berat kapal meliputi titik berat baja, power plant, permesinan, equipment and outfitting dan consumable. Pendekatan titik berat tersebut dihitung dengan rumus yang disajikan oleh Parson pada Parametric Ship Design Chapter 11 sehingga mendapatkan LCG total. Besarnya LCG total dari hasil perhitungan pendekatan LCG tersebut adalah trim $=2,328 \mathrm{~m}$, dengan kondisi trim buritan.

Adapun batasan yang diberikan untuk trim adalah $0.05 \% \mathrm{~L}$ $=7,775 \mathrm{~m}$ dan LCG-LCB $=3,164 \mathrm{~m}$. Karena trim < batasan trim, maka koreksi trim kapal diterima.

Perhitungan lambung timbul (freeboard) kapal dihitung berdasarkan International Convention Load Lines (ILCC),1966. Menurut ILCC 1966, kapal pembangkit listrik tenaga gas yang didesain termasuk dalam kategori kapal tipe B. Sehingga untuk perhitungan selanjutnya menggunakan acuan perhitungan kapal tipe B.

Freeboard standart yaitu freeboard yang tertera pada tabel freeboard standar sesuai dengan tipe kapal. Untuk tipe kapal B dengan panjang $155,5 \mathrm{~m}$ sebesar $2429 \mathrm{~mm}$.

Berikut ini merupakan koreksi-koreksi freeboard sesuai dengan ILCC 1966,

1) Koreksi koefisien blok (untuk kapal dengan $\mathrm{Cb}>0.68$ )

$$
\mathrm{Fb}_{2}=2475,570 \mathrm{~mm}
$$

2) Koreksi tinggi $\left(\mathrm{Fb}_{3}\right)$

Koreksi dilakukan apabila D > L/15

$\mathrm{Fb}_{3}=3883,904 \mathrm{~mm}$

Lambung timbul minimum adalah penjumlahan dari semua koreksi untuk mendapatkan tinggi lambung timbul minimum.

Lambung timbul (Freeboard) minimum $\quad=8788,474 \mathrm{~mm}$

Dari perhitungan batasan yang telah dibuat didapat nilai lambung timbul minimum adalah $8788,474 \mathrm{~mm}$. Lambung timbung dari kapal yang didesain adalah $9000 \mathrm{~mm}$. Jadi lambung timbul kapal PLTG yang didesain telah memenuhi standar.

Perhitungan stabilitas kapal PLTG dilakukan dengan menggunakan bantuan software Maxsurf Stability Advanced Education Version. Berat dan titik berat LWT kapal menjadi input dalam software ini, sedangkan untuk tangki-tangki consumable beserta ballast kapal PLTG akan dimasukkan sesuai dengan kebutuhan dan posisi tangki pada perhitungan. Batasan untuk perhitungan stabilitas kapal yang didesain adalah berdasarkan IMO (IS Code, Annex 749(18)) [6]. Selain kriteria hal yang diperlukan adalah data loadcase (LC). Dalam perhitungan ini dilakukan tiga variasi loadcase, antara lain loadcase dengan kondisi consumable 100\%, 60\%, dan 30\% Berikut adalah rangkuman hasil perhitungan stabilitas yang telah dibandingkan dengan batasannya, 
Tabel 4.

Rangkuman hasil perhitungan stabilitas kapal PLTG

\begin{tabular}{|c|c|c|c|c|c|}
\hline Data & $\begin{array}{c}\text { LC } \\
100 \%\end{array}$ & $\begin{array}{c}\mathrm{LC} \\
60 \%\end{array}$ & $\begin{array}{c}\mathrm{LC} \\
30 \%\end{array}$ & $\begin{array}{c}\text { Kriteria } \\
\text { IMO }\end{array}$ & Kondisi \\
\hline $\mathrm{e}_{30^{\circ}}{ }^{\text {(m.deg}}$ & 40,581 & 39,414 & 39,453 & $\geq 3,1513$ & Diterima \\
\hline $\mathrm{e}_{40}{ }^{\mathrm{o}}(\mathrm{m} \cdot \mathrm{deg})$ & 71,358 & 69,234 & 69,220 & $\geq 5,1566$ & Diterima \\
\hline $\mathrm{e}_{30-40^{\circ}}(\mathrm{m} . \mathrm{deg})$ & 30,776 & 29,820 & 29,767 & $\geq 1.7189$ & Diterima \\
\hline $\mathrm{h}_{30}{ }^{\mathrm{o}}(\mathrm{m})$ & 3,195 & 3,090 & 3,083 & $\geq 0.2$ & Diterima \\
\hline$\theta_{\max }(\mathrm{deg})$ & 39,1 & 39,1 & 39,1 & $\geq 25$ & Diterima \\
\hline $\mathrm{GM}_{0}(\mathrm{~m})$ & 4,588 & 4,391 & 4,373 & $\geq 0.15$ & Diterima \\
\hline
\end{tabular}

Keterangan :

$\mathrm{e}_{30}{ }^{\circ}$ adalah luas bidang dibawah kurva lengan statis (GZ) sampai $30^{\circ}$ sudut oleng,

$\mathrm{e}_{40^{\circ}}$ adalah luas bidang dibawah kurva lengan statis (GZ) sampai $40^{\circ}$ sudut oleng,

$\mathrm{e}_{30-40^{\circ}}$ adalah luasan bidang yang terletak di bawah lengkung lengan statis (GZ) diantara sudut oleng $30^{\circ}$ dan $40^{\circ}$

$\mathrm{h}_{30^{\circ}}$ adalah lengan statis (GZ) pada sudut oleng $>30^{\circ}$.

$\theta_{\max }$ adalah sudut dimana lengan stabilitas statis (GZ) maksimum terjadi.

$\mathrm{GM}_{0}$ adalah tinggi metacentre (MG) pada sudut oleng $0^{\circ}$.

Kemudian dilanjutkan dengan pembuatan Lines Plan dan General Arrangement. Pembuatan Lines Plan menggunakan bantuan dari software Maxsurf Education Version dan CAD. Lines Plan yang dihasilkan menjadi acuan dalam pembuatan General Arrangement kapal PLTG. Dalam pembuatan General Arrangement menggunakan referensi dari layout kapal PLTG yang beroperasi.

\section{KESIMPULAN}

Dari perhitungan dan analisa yang telah dilakukan, didapatkan besar output daya listrik dan ukuran utama kapal PLTG yang didesain. Selanjutnya diketahui bahwa perhitungan ini telah memenuhi margin berat kapal, batasan trim, freeboard kapal, dan kriteria-kriteria IS Code untuk stabilitas kapal. Didapatkan pula desain Lines Plan dan General Arrangement kapal PLTG. Untuk detail dari kesimpulan Tugas Akhir, dapat dilihat sebagai berikut:

1) Output daya listrik dari kapal yang didesain sebesar 144 MW.

2) Ukuran utama kapal pembangkit listrik tenaga gas yang didesain $\mathrm{Lpp}=155,5 \mathrm{~m}, \mathrm{~B}=31 \mathrm{~m}, \mathrm{H}=16 \mathrm{~m}, \mathrm{~T}=7 \mathrm{~m}$.

3) Perhitungan teknis yang dilakukan telah memenuhi.

a. Perhitungan berat yang telah dilakukan menghasilkan margin berat sebesar 3,79\%. Displacement kapal adalah 25397,911 ton dan berat kapal (LWT+DWT) adalah 24435,315 ton.

b. Perhitungan trim yang telah dilakukan menghasilkan hasil 2,328 $\mathrm{m}$, batasan trim maksimal adalah sebesar 3,164 m. Sehingga perhitungan trim telah memenuhi.

c. Perhitungan lambung timbul yang telah dilakukan menghasilkan batasan lambung timbul sebesar 8,788 $\mathrm{m}$, lambung timbul kapal sebenarnya adalah $9 \mathrm{~m}$. Sehingga perhitungan lambung timbul diterima. d. Perhitungan stabilitas yang dilakukan menggunakan acuan regulasi dari IMO IS Code. Hasil yang didapatkan semua parameter stabilitas telah terpenuhi.

4) Desain Lines Plan telah dibuat dan dapat dilihat dari Gambar 2.

5) Desain General Arrangement telah dibuat dan dapat dilihat dari Gambar 2.

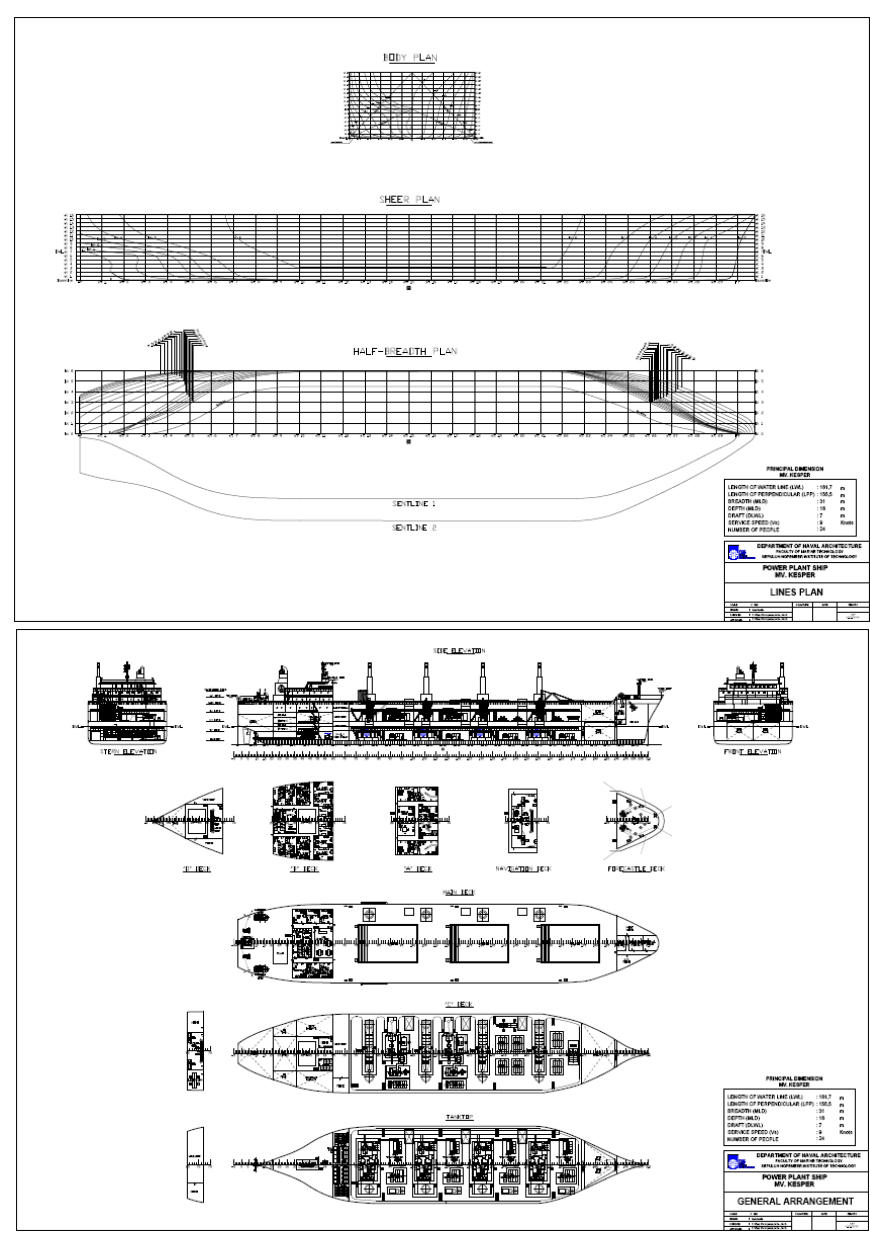

Gambar. 3. Desain Lines Plan dan General Arrangement kapal Pembangkit Listrik Tenaga Gas (PLTG).

\section{UCAPAN TERIMA KASIH}

Ucapan terimakasih Penulis tujukan, yang pertama kepada Bapak Ir. Wasis Dwi Aryawan, M.Sc., Ph.D. selaku dosen pembimbing, Bapak Dr. Ir. I Ketut Suastika sebagai dosen wali Penulis. Kedua kepada Ayah dan Ibu yang telah memberikan dukungan doa dan biaya demi terselesaikannya Tugas Akhir ini. Ketiga kepada teman-teman dan pihak-pihak yang tidak dapat Penulis sebutkan satu per satu.

\section{DAFTAR PUSTAKA}

[1] E. V. Lewis, Principle of Naval Architecture Volume 1, Jersey City, NJ: The Society of Naval Architecture \& Marine Engineers, 1998.

[2] D. G. Watson, Practical Ship Design, Kidlington: Elsevier, 1998.

[3] E. V. Lewis, Principle of Naval Architecture Volume II, Jersey City, NJ: The Society of Naval Architecture and Marine Engineers, 1988. 
[4] S. V. B. H., Ship Design for Efficiency and Economy, Woburn: Butterwoth Heinemann, 1998.

[5] M. G. Parsons, Parametric Design Chapter 11 in Ship Design and Construction, New York: The Society of Naval Architects and Marine Engineers, 2003.

[6] International Maritime Organization (IMO), Interpretations of the International Convention on Load Lines, London: International Association of Classification Societies, 1996. 